\title{
Emission Reduction Study for Eco-Campus Program, Case Study in Sepuluh Nopember Institute of Technology Indonesia
}

\author{
Ridho Hantoro $^{1 *}$, Detak Yan Pratama ${ }^{2 *}$, Endah Laksmi Nugraha ${ }^{3}$, Rizky Nanda Puspitasari ${ }^{4}$ \\ Engineering Physic Department, Institut Teknologi Sepuluh Nopember (ITS), Surabaya, Indonesia ${ }^{1,2,3,4}$ \\ Corresponding author: ${ }^{{ }^{*}}$ hantoro@ep.its.ac.id, ${ }^{2 *}$ detak@ep.its.ac.id
}

\begin{abstract}
Emission of $\mathrm{CO}_{2}$ in Indonesia is high relatively and have reached 1,55-ton carbon $\left(5,67\right.$ ton $\mathrm{CO}_{2}-$ eq) per capita. It is predicted to increase up to 3,22-ton carbon per capita in 2050 as increasing of population growth. Indonesian Government has issued the policy for decreasing greenhouse gasses effect below $26 \%$ in 2020. It proposed to all of society not only public and private institutions, but also education institution like campus. This study is aimed to identify the factors which can influence greenhouse gasses effect, including carbon emission in transportation, waste management and electrical consumption in Sepuluh Nopember Institute of Technology (ITS). It is projected to support implementation of ITS eco campus program more effectively. Therefore, this study has formulated local planning and policy which can be implemented by campus community to decrease carbon emission and organize ITS as real eco-campus.
\end{abstract}

Keywords—carbon emission, policy, eco-campus, $G H G$

\section{INTRODUCTION}

$\mathrm{C}$ limate change that is affected by human activity caused differences in composition and concentration of greenhouse gasses emission (GHG) globally. According IPCC 2006, climate change will cause in changing of temperature, increasing sea level, precipitation, and the worst scenario is extreme change that lead to natural disasters. As following of gross domestic product (GDP), carbon emission in Indonesia reach 1,55-ton carbon $\left(5,67\right.$ ton $\mathrm{CO}_{2}-$ eq). It can reach 3,22 -ton carbon in 2050 , due the population growth without considering GHG mitigation or based on business as usual [1]. Projection from Indonesian government, for high emission sectors can reduce $26 \%$ GHG until 2020 (2009 United Nations Climate Change Conference) [2]. This reduction action can be applied in decentralized sector like campus. Role of low carbon society is expected to support national aim for reducing GHG emission. Strategic planning, consensus making, and coordination are some tools for make it happen [3].

To support reducing GHG emission projection [4], mapping the carbon emission need to be done in a certain environment, such as campus. This effort can lead to know prediction of increasing emissions produced, and potential issue that can help achieving projection. The result of this study is formulating grand design to reduce GHG emission, especially carbon, can be achieved to become low carbon society campus.

\section{METHOD}

\section{A. Identification}

Data and identification is needed to investigate prediction of carbon emission in campus. Profile of the campus or basic information will help the identification, previous data of emission in 5 years, physical conditions, green open space condition, and sources of the emission in campus environment. Identity the policy and standard used in the ecocampus program also one of the main data that is used as comparison [5].

In this study took case at a campus in Surabaya Indonesia. It has total area 180 ha and area of the building more than $150.000 \mathrm{~m}^{2}$. Map of the campus is presented in Figure 1.

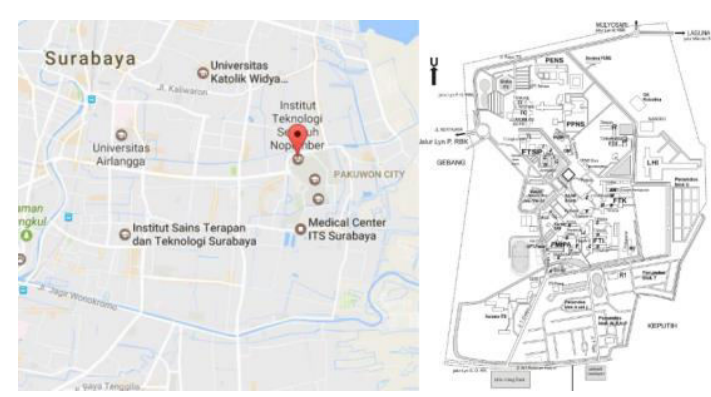

Figure 1. Map of the Case Study (Campus in Indonesia)

\section{B. Discussion}

Emission calculation based on real time data and information collection will lead analysis and discussion to achieve emission mapping and recommendation to reduce carbon emission. Calculation and analysis can be reached by.

(a) Calculation of carbon emission around campus environment,

(b) Air pollution dispersion using Gauss Lone Source Dispersion Model,

(c) Mapping carbon emission using tools, 
(d) Calculation of green open space capabilities in reduced the carbon emissions.

\begin{tabular}{ccc} 
& Table 1. Air Pollution Index in Indonesia \\
\hline CATEGORY & RANGE & DESCRIPTION
\end{tabular}

\begin{tabular}{|c|c|c|}
\hline CATEGORY & RANGE & DESCRIPTION \\
\hline Good & $0-50$ & $\begin{array}{l}\text { Safe for health of human and animal, so does plant, building, even } \\
\text { aesthetic on environment }\end{array}$ \\
\hline Average & $51-100$ & $\begin{array}{l}\text { Safe for health of human and animal, but give some effects to } \\
\text { sensitive plants and environmental aesthetic }\end{array}$ \\
\hline Not Healthy & 101-199 & $\begin{array}{l}\text { Harm for health of human, sensitive animal, and spoil plants as } \\
\text { aesthetic environment }\end{array}$ \\
\hline Harm & $200-299$ & Harm for health of exposed population \\
\hline Dangerous & 300-more & Causing serious damage on health population \\
\hline
\end{tabular}

C. Recommendation for Emission Reduction

Recommendation and policy decision would be based on the calculation of carbon emissions prediction and mapping in campus. This policy will be considered with the work program that eco-campus had. So, it is expected to reduce carbon emission levels in campus briefly.

\section{RESULTS AND DISCUSSION}

\section{A. Emission Standard}

Indonesian government through minister of the environment established air pollution index as standard air quality in Indonesia. Air pollution standard describe the air quality in certain location and time. This index referring the effect to health, aesthetics, and other things. The air pollution index measures some particulates as measured variable such as PM10, $\mathrm{CO}$, sulfur dioxide $\left(\mathrm{SO}_{2}\right)$, nitride dioxide $\left(\mathrm{NO}_{2}\right)$, and ozone $\left(\mathrm{O}_{3}\right)$. Table 1 describing the range of air pollution index as used.

\section{B. Eco-Campus Program}

Eco-Campus really considered of environmental issues. Eco campus program involved emission reduction with maximized green open space, reduction in used electricity, water conservation, low emission transportation inside campus, and waste management.
To increase green open space sectors, cultivation of trees, on green open space sectors is the main program. Bike to share program is provided to academicians and students, it will support low emission transportation in campus. Waste management is action that required to manage waste until its final disposal, one of the step is waste treatment. In eco-campus program waste is used as power plant. The organic and inorganic waste potential in campus reach $2-4 \mathrm{~m}^{3}$ every day. It can be converted to $3 \mathrm{~kW}$ electricity.

\section{Emission Source}

The source of emission is from some aspects, such as.

\section{(1) Transportation}

The number of motor vehicles in the campus environment is obtained by calculating the number and type of vehicles that go through four entrances during peak hours. Data on the number of vehicles taken during holiday time (non-active) and time effective lectures (active) [6]. Details on Table 2.

The transport fuels used are gasoline and diesel. Type of transportation that generally exist on campus is motorcycles and cars. From the results of data retrieval, it is known that the number of vehicles increased by $74.54 \%$ by the time of data collection.

Table 3 shows the increase in carbon emissions in the active and non-active time. The largest increase occurred in the afternoon that is equal to $69.06 \%$.

Table 2. Number of Vehicles During Holiday Time (Non-Active) and Time Effective Lectures (Active)

\begin{tabular}{lllll}
\hline \multirow{2}{*}{ Time } & \multicolumn{1}{c}{ Specification } & Non-active & Active & $\begin{array}{c}\text { Enhancement } \\
(\%)\end{array}$ \\
\hline \multirow{2}{*}{$07.00-08.00$} & Motorcycle & 4140 & 11105 & 168.24 \\
& Gasoline Car & 1462 & 2037 & 39.33 \\
& Diesel used Car & 162 & 172 & 6.17 \\
\hline \multirow{2}{*}{$12.00-13.00$} & Motorcycle & 4933 & 12387 & 151.10 \\
& Gasoline Car & 1517 & 2263 & 49.18 \\
\hline \multirow{3}{*}{$16.00-17.00$} & Diesel used Car & 144 & 174 & 20.83 \\
& Motorcycle & 6489 & 14059 & 116.66 \\
\hline Average of Enhancement & Gasoline Car & 1488 & 2380 & 59.95 \\
\hline
\end{tabular}


Table 3. Emission from Transportation in Campus During Active and Non-Active Time

Time $\begin{array}{r}\text { Emission in } \\ \text { time (g) } \\ \text { 127.00-08.00 } \\ 16.00-13.00\end{array}$
63.78 .00
64.74
Average of Enhancement
During holidays, major carbon emissions by an
average of $65.69 \mathrm{~g} / \mathrm{sec}$, whereas during the active
days of lectures magnitude of carbon emissions is
107.86\%. Although the motorcycles are the most
number of vehicles crossing the ITS, but cars are the
largest carbon emission contributor.
(2) Waste Treatment
There are two types of waste in campus, organic
and inorganic waste. Every day the production of
waste that is capable of being transported in a day
reached 480.6 kg. As for the organic waste that can be
produced in campus are 1.07 tons a month. So, that the
estimated total emissions from organic waste is 0.3424
ton / year.

\section{(3) Electrification}

For Electricity supply in the campus there are two sources, it comes from grids and diesel generator [7]. This generator usually used as back up electricity when the grids are down. From the campus case study has 15 generators and used 7800 liters in 5 years. And for the emission that occurred from the generators can be obtained from equation below.

$$
\text { Fuel }_{a}=\text { fuel amount } \times \text { Energy Content }
$$

$$
\text { Emission }=\sum_{a}\left[\text { Fuel }_{a} \times E F_{a}\right]
$$

\begin{tabular}{lcc}
$\mathbf{m e}(\mathbf{g r} / \mathbf{s e c})$ & $(\mathbf{g r} / \mathbf{s e c})$ & $\mathbf{( \% )}$ \\
\hline 63.78 & 98.85 & 54.98 \\
64.74 & 108.82 & 68.10 \\
68.54 & 115.89 & 69.09 \\
\hline $\mathbf{6 5 . 6 9}$ & $\mathbf{1 0 7 . 8 6}$ & $\mathbf{6 4 . 0 6}$ \\
\hline
\end{tabular}

The fuel for diesel generators reach 140 liters/month or $119,1 \mathrm{~kg} / \mathrm{month}$ and with the calculation carbon emission for each generator is $401,266 \mathrm{~kg} / \mathrm{month}$.

D. Emission Mapping

(1) Gauss Dispersion Model Line Source

Gauss dispersion model line source is used to determine the spread of pollutants based on line source with calculation of mathematical Gauss Dispersion Model. There are several approaches in this model, based on this approach, can be derived into gauss model for the dispersion of pollutants in the air-type line source.

$$
C_{(X, Y, Z)}=\left[\frac{2 Q}{\sin \theta \sqrt{2 \pi} \times \tau z \times u}\right] \times\left[e^{-\frac{1}{2} \times\left(\frac{H e}{\tau z}\right)^{2}}\right]
$$

To determine the dispersion carbon emission pattern, the case study-campus divided into eight sections mapping.

\section{(2) Carbon Emission Mapping in Campus}

Data calculation of air pollutant concentrations are plotted using Surfer in accordance with the zoning and point coordinates that have been determined. Figure 2 and $\mathbf{3}$ represented the spread of emissions in active and non-active campus periods.

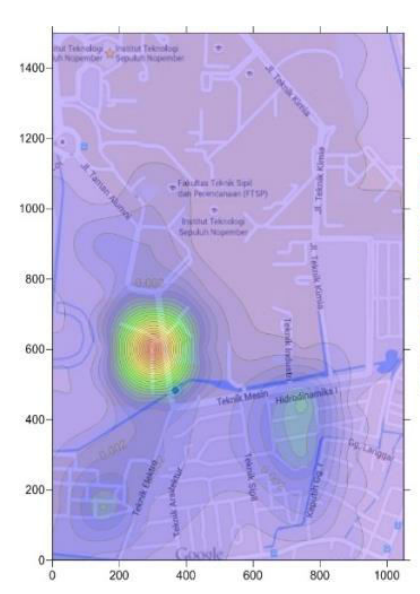

a
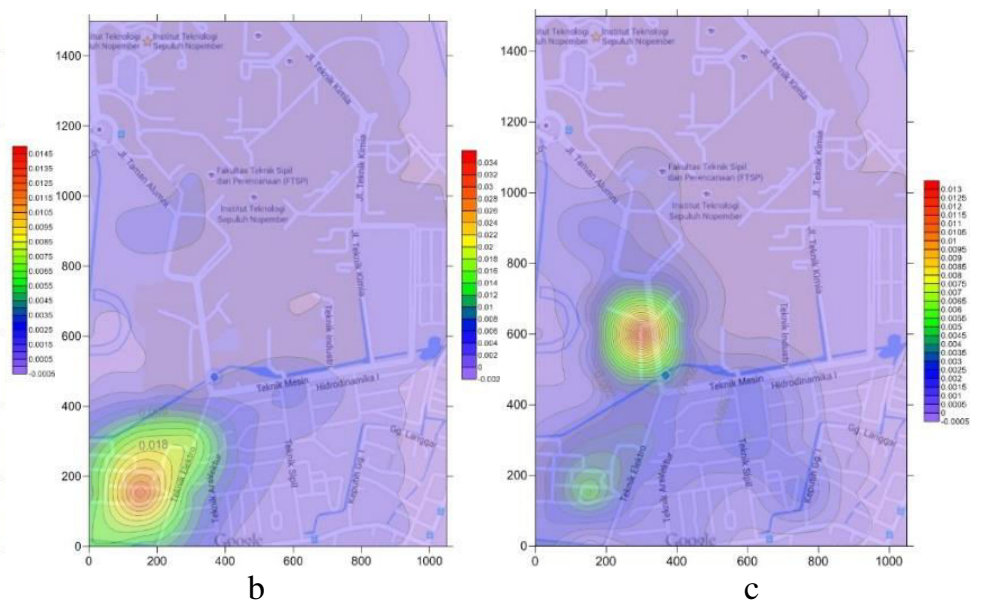

Figure 2. Emission Contour Mapping in Campus at (a)08.00 - 09.00 (b)12.99-13.00 (c) 16.00-17.00 on Active Period 

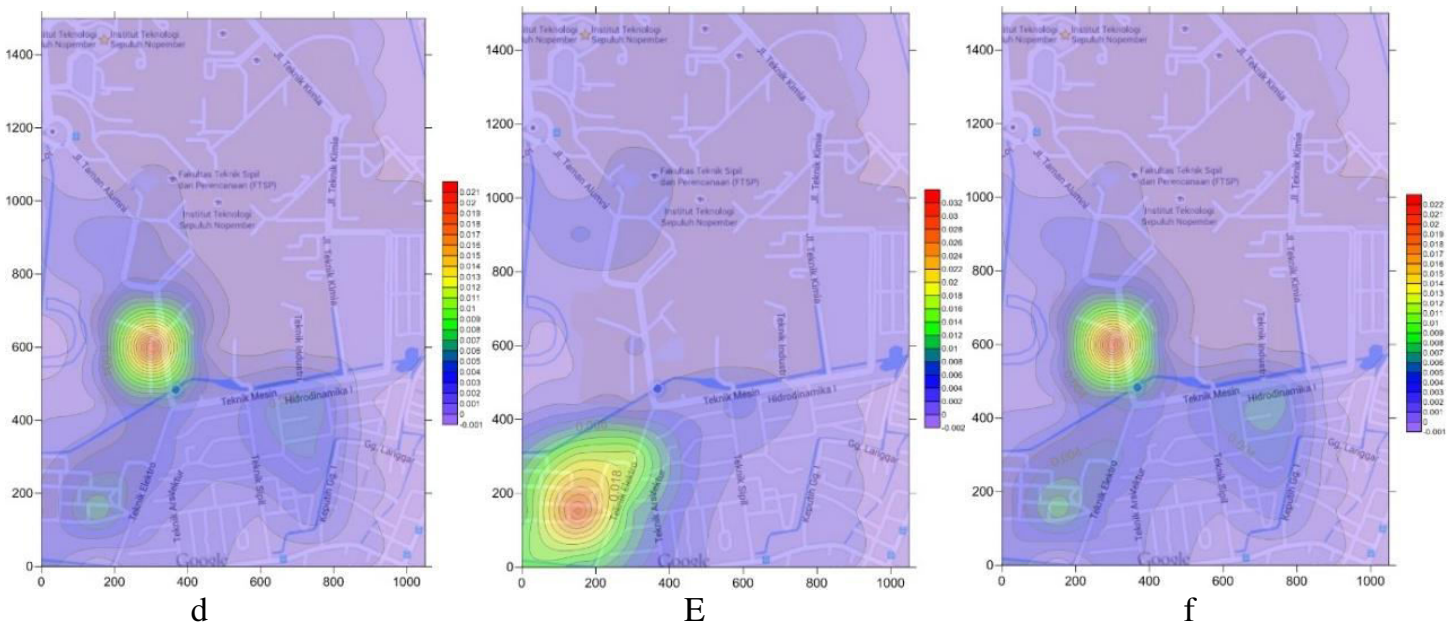

Figure 3. Emission Contour Mapping in Campus at (a)08.00 - 09.00 (b)12.99-13.00 (c) 16.00-17.00 on NonActive Period

Table 4. Carbon emission absorption based on the tree type

\begin{tabular}{lllll}
\hline Types of Tree & Quantity & $\begin{array}{l}\text { Carbon } \\
\text { (kg/tree/year) }\end{array}$ & $\begin{array}{c}\text { Absorption } \\
\text { Carbon Absorption } \\
\text { (kg/year) }\end{array}$ & $\begin{array}{c}\text { Carbon Absorption } \\
\text { (g/sec) }\end{array}$ \\
\hline Trembesi & 208 & 28448,39 & 5917265 & 187,6352 \\
Beringin & 60 & 535,9 & 32154 & 1,0196 \\
Kiara payung & 87 & 404,83 & 35220,21 & 1,1168 \\
Mahoni & 28 & 295,73 & 8280,44 & 0,2626 \\
Jati & 43 & 135,27 & 5816,61 & 0,1844 \\
Nangka & 5 & 126,51 & 632,55 & 0,0201 \\
Johar & 37 & 116,25 & 4301,25 & 0,1364 \\
Sirsak & 1 & 75,29 & 75,29 & 0,0024 \\
Akasia & 75 & 48,68 & 3651 & 0,1158 \\
Flamboyan & 22 & 42,2 & 928,4 & 0,0294 \\
Sawo & 32 & 36,19 & 1158,08 & 0,0367 \\
Tanjung & 86 & 34,29 & 2948,94 & 0,0935 \\
Bambu & 8 & 12 & 96 & 0,0030 \\
Angsana & 156 & 11,12 & 1734,72 & 0,0550 \\
Asam kranji & 35 & 8,48 & 296,8 & 0,0094 \\
Dadap merah & 28 & 4,55 & 127,4 & 0,0040 \\
Asem & 4 & 1,49 & 5,96 & 0,0002 \\
\hline \multicolumn{7}{l}{ TOTAL Carbon absorption in Campus } & 190,7247 \\
\hline
\end{tabular}

\subsection{Green Open Space Condition}

Campus in the case study has enough green open space. Based on campus data, 82,25 Ha is green space that planted various plants, and most the plants are as habitat various bird in campus. Campus has reforestation program which implemented with tree rejuvenation, seeding for particular plant, and doing periodic reforestation, named Gugur Gunung. Total plants that planted are 12486 trees which has different carbon emission absorption for each type. Plants has natural ability to reduced carbon emission. Plant's ability in absorbing carbon is vary. So that in planting crops is often selected a type of tree that has high carbon absorption [8]. Table 4 is presented the total carbon emission absorption in the case study campus.
4.6 Emission Projection

The number of vehicles in the campus environment are growing through years. Based on predictions, the number of cars that exist in ITS in 2020 is about 7,250 units.Based on data retrieval which is done from 2015, about $8 \%$ of the total number of cars is used Diesel fuel. So, by taking the same assumption then in 2020 will get the car with gasoline with the amount of 6,670 units and cars with diesel fuel with a total of 580 units. Based on 2006 and 2010 data and data capture from 2015, there are visible increase in vehicles number. Carbon emission affected to this growth. Benchmarking is used, based on data 2006,2010, and 2015, the predicted number of vehicles in campus is presented in Figure 4. 
The Third International Conference on Civil Engineering Research (ICCER)

August $1^{\text {st }}-2^{\text {nd }}$ 2017, Surabaya - Indonesia
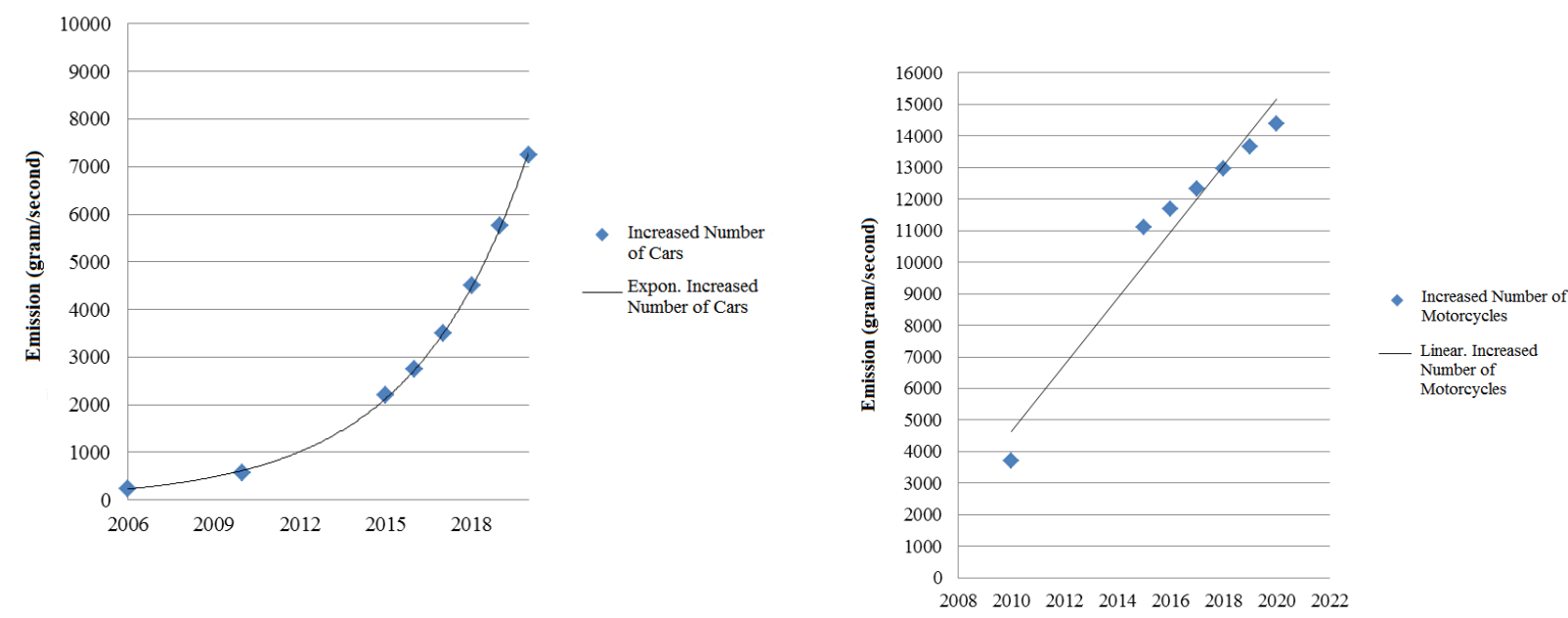

Figure 4. Predicted Vehicle in Campus until 2020

Table 5. Emission Prediction of Vehicles in Campus

\begin{tabular}{ccccc}
\hline Year & $\begin{array}{c}\text { Emission from } \\
\text { Motorcycles } \\
\text { (gram/second) }\end{array}$ & $\begin{array}{c}\text { Emission from } \\
\text { Gasoline-Cars } \\
\text { (gram/second) }\end{array}$ & $\begin{array}{c}\text { Emission from } \\
\text { Diesel-Cars } \\
\text { (gram/second) }\end{array}$ & $\begin{array}{c}\text { Total Emission } \\
\text { (gram/second) }\end{array}$ \\
\hline 2015 & 219.00 & 713.67 & 67.44 & 1001.09 \\
2016 & 231.67 & 885.34 & 83.52 & 1200.53 \\
2017 & 243.97 & 1120.91 & 106.68 & 1481.56 \\
2018 & 256.93 & 1454.03 & 137.16 & 1848.12 \\
2019 & 270.57 & 1857.93 & 175.26 & 2303.76 \\
2020 & 284.94 & 2342.60 & 220.98 & 2848.52 \\
\hline
\end{tabular}

Table 6. Emission Prediction by Considering the Absorption Ability of the Plant

\begin{tabular}{ccccccc}
\hline Year & $\begin{array}{c}\text { Emission } \\
\text { from } \\
\text { Motorcycles } \\
\text { (gram/second) }\end{array}$ & $\begin{array}{c}\text { Emission } \\
\text { from } \\
\text { Gasoline- } \\
\text { Cars } \\
\text { (gram/second) }\end{array}$ & $\begin{array}{c}\text { Emission } \\
\text { from Diesel- } \\
\text { Cars } \\
\text { (gram/second) }\end{array}$ & $\begin{array}{c}\text { Total } \\
\text { Emission } \\
\text { (gram/second) }\end{array}$ & $\begin{array}{c}\text { Emissions } \\
\text { Absorbed by } \\
\text { Plants } \\
\text { (gram/second) }\end{array}$ & $\begin{array}{c}\text { Final } \\
\text { Emission } \\
\text { (gram/second) }\end{array}$ \\
\hline 2015 & 219.00 & 713.67 & 67.44 & 1001.09 & 190.72 & 810.37 \\
2016 & 231.67 & 885.34 & 83.52 & 1200.53 & 190.72 & 1009.81 \\
2017 & 243.97 & 1120.91 & 106.68 & 1481.56 & 190.72 & 1290.84 \\
2018 & 256.93 & 1454.03 & 137.16 & 1848.12 & 190.72 & 1657.40 \\
2019 & 270.57 & 1857.93 & 175.26 & 2303.76 & 190.72 & 2113.04 \\
2020 & 284.94 & 2342.60 & 220.98 & 2848.52 & 190.72 & 2657.80 \\
\hline
\end{tabular}

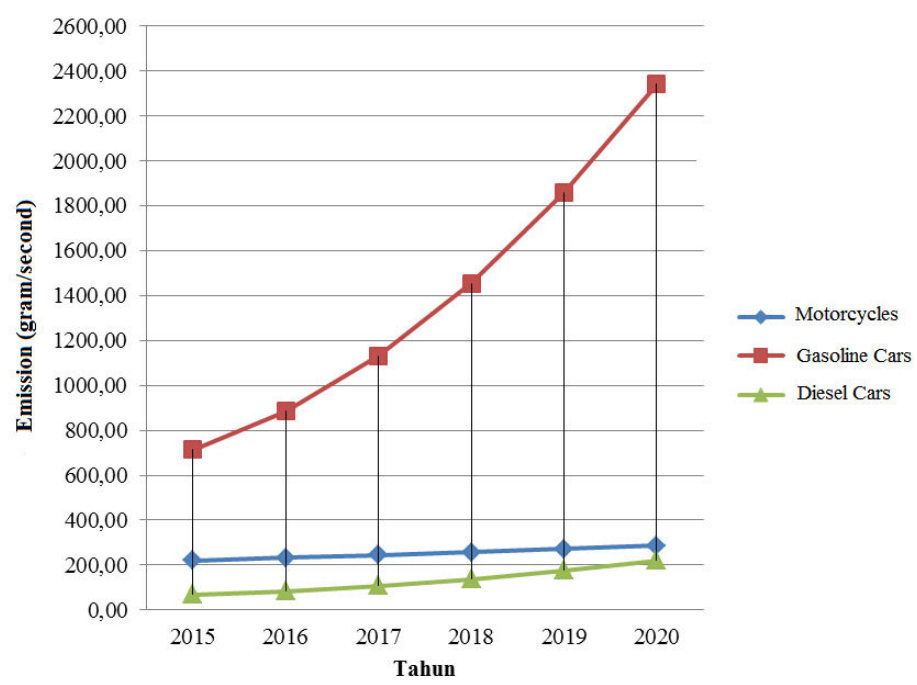

Figure 5. Prediction of Emission Emitted by Vehicles until 2020 


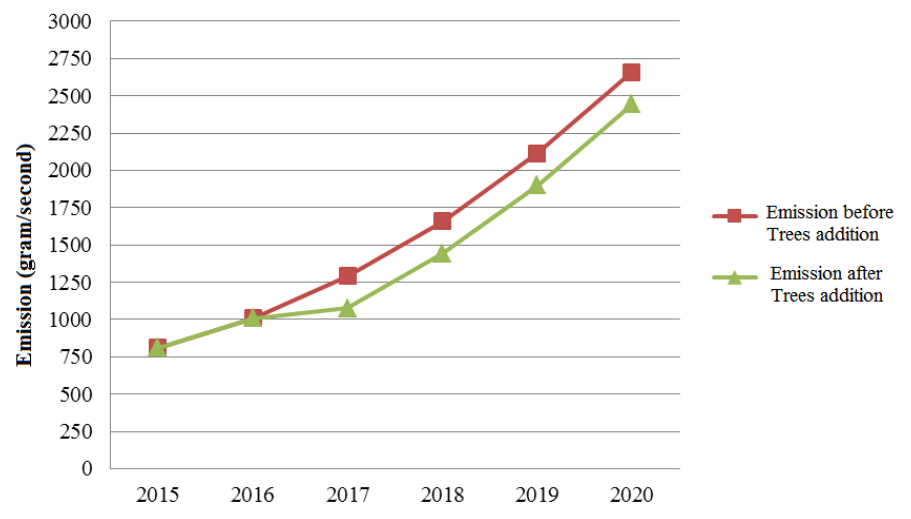

Figure 6. Projection of Emission with Plantation

In contrast to the increase in the number of car that exponentially shaped. The increase in the number of motorcycles on campus tend to be linear with an increase of $5.31 \%$ annually. And predictions carbon emissions based on the predicted number of vehicles in the campus can be seen in Figure 5 and Table 5.

Based on the vehicle prediction that increased by the year. If there is no attempt to suppress the number of vehicle, it will affect every year carbon emissions. The carbon emission will be increased and by 2020 the total emission reach 2848.52 grams of CO2/ second. There is an effort to reduce the rate of carbon emission in the campus with planting high carbon absorption ability of plants. It shown in Table 6 . Prediction of emission after plantation of plants.

The increased total carbon emissions from the transport sector can be reduced by the ability of the vegetation in the ITS environment to absorb $\mathrm{CO} 2$. In order to reduce the addition of carbon emissions annually can be achieved by addition of a tamarind. This is because a tamarind has a high $\mathrm{CO} 2$ absorption that is $28448.39 \mathrm{~kg}$ / tree / year. By estimating the time began planting trees in 2016 and the fall looks began in 2017 as many as 450 pieces. Then the expected decline as shown in Figure 6.

\section{CONCLUSION}

According to calculation and research about carbon emission source in campus, there are emission carbon policies recommendation for campus environment. Turning to campus bike inside campus. This mass transportation will support one of eco-campus program, campus bike. Using environmentally friendly mass transportation inside campus like shuttle bus. Planting 450 tamarind and tree that has high absorption on carbon. This implantation is done in some spot which has high carbon emission.

\section{ACKNOWLEDGEMENTs}

To accomplish eco-campus program which has environment care culture, Academicians need to support by decreasing greenhouse emission especially carbon that will endanger ozone layer. Therefore, campus must have plan and policy to decrease carbon emission and create eco-campus that care and has good culture to environment

\section{REFERENCES}

[1] E. F. Nugraheni, "A Study on Energi Efficiency In Campus Buildings," Engineering Department ITS, Surabaya, 2014.

[2] Bagian Proyek Pelaksanaan Efisiensi Energi Departemen Pendidikan Nasional, "Pedoman Pelaksanaan Konservasi Energi dan Pengawasannya di Lingkungan DEPDIKNAS," DEPDIKNAS, Jakarta, 2002.

[3] Widyastuti, R. Hantoro, A. B. K. Putra, E. Novianarenti and A. G. Safitra, "Improved Energi Saving for R22 Building Air Conditioning Retrofitted with Hydrocarbon Refrigerant, Study Case: Civil Engineering Department of ITS," in 1st International Conference on Mechanical of Engineering ITS (ICOME 2013), Surabaya, 2013.

[4] Widyastuti, A. B. K. Putra and R. Hantoro, "Konservasi Energi Sektor Bangunan di Lingkungan Kampus ITS Surabaya sebagai salah Satu Pengurangan Emisi karbon dalam Program Eco Campus," BOPTN ITS, Surabaya, 2013.

[5] G. Janssens-Maenhout, J. A. H. W. Peters, J. G. J. Olivier and W. J., "Longterm Trend In Global CO2 Emissions," The Hague: PBL/JRC, Netherlands, 2011.

[6] R. Hantoro and E. Soedjono, "Pengembangan Master Plan Pengurangan Emisi Gas Rumah Kaca Kota Surabaya," BAPPEKO Surabaya, Surabaya, 2012.

[7] A. Aziz, "Pemetaan Kecukupan Vegetasi untuk Mereduksi Konsentrasi Karbon Dioksida (CO2) di Kampus ITS Surabaya," ITS Surabaya, Surabaya, 2010.

[8] S. R. Sitohang, "Pemetaan Distribusi Konsentrasi Kadbon Dioksida (CO2) dari Kontribusi Kendaraan Bermotor di Kampus ITS Surabaya," ITS Surabaya, Surabaya, 2010. 